\title{
The voluntary intake and utilization of forage-concentrate diets by ewes in late pregnancy
}

\author{
Teresa Castro', F.F. Bermúdez $z^{2}$, C. Valdés ${ }^{2}$, A.R. Mantecón ${ }^{2}$, \\ T. Manso ${ }^{1}$ and I. Salzar ${ }^{1}$ \\ 'Departamento de Producción Animal \\ Facultad de Veterinaria, 28040, Madrid, Spain \\ 2Estacion Agricola Experimental (CSIC) \\ Aptdo 788. 24080 León, Spain
}

(Received 16 September 1994; accepted 23 Scptember 1994)

\begin{abstract}
The objectives of this study were to examine the effects of concentrate intake on voluntary intake of forage by Churra ewes in late pregnancy. Three levels of concentrate $(0,300$ and $600 \mathrm{~g} / \mathrm{d}$ ay $)$ with two hays available on an ad lihitum basis (lucerne, $\mathrm{DMD}=66.6 \%$ ) and pasture (DMD $-70.0 \%$ ) were fed to 36 pregnant Churra ewes from day 110 of pregnancy until lambing. Ewes receiving roughage only had slightly higher intake of pasture hay than lucerne hay but when concentrate was fed, voluntary intake of lucerne tended to be higher. Offering more concentrate to the ewes reduced voluntary intake of hays with a greater decline for the pasture hay. As pregnancy progressed, hay intake increased and reached its maximum during the 18th weck of pregnancy. Ewes within treatments showed similar total DM intake. A predictive equation may derive hay intake from hay digestibility, concentrate intake, ewe live weight and litter weight.
\end{abstract}

KEY WORDS: pregnant cwes, voluntary intake, supplementation

\section{INTRODUCTION}

The Churra breed is the most important nucleus of milk-producing sheep in Spain. Feeding systems used are variable in productive levels and available pastureland. Generally, Churra sheep graze pasture in many shecp-farming systems. In these circumstances, a cereal-based supplement is usually provided.

Nutrient requirements of ewes in late pregnancy have been presented $(\Lambda \mathrm{RC}$, 1980; NRC, 1985; INRA, 1988) and have also been described for Churra ewes (Guada and Ovejero, 1977; Castrillo and Guada, 1979). To meet these 
requirements, it is necessary to predict intakes of different feeds in addition to knowing their nutrient contents. Physical limitation of intake during the last week of pregnancy impedes meeting the high requirements of this physiological state (Forbes, 1970). Quality of forage and amount of concentrate can modify voluntary intake of forage depending on changes in digestibility and palatability of the diet (Bocquier et al., 1987; Orr and Treacher, 1984; Orr et al., 1985).

At present, there are few data on the intake of forage, especially as a component of a mixed diet, by pregnant Churra ewes. This paper describes an experiment studying voluntary intake of hay by pregnant Churra ewes receiving diets with threc levels of concentrate.

\section{MATERIAL AND METHODS}

\section{Animals}

The experiment was conducted with 36 pregnant Churra ewes from 110 days of pregnancy until lambing. Body weight ranged from 60 to $70 \mathrm{~kg}$. On days 110 of pregnancy the ewes were divided into homogeneous groups according to body weight and experimental diets were randomly applied. The ewes were individually penned until lambing. After 10 days of adaptation, feed intake of each animal was registered.

\section{Treatments}

The experiment utilized a factorial arrangement of treatments with two types of hay (lucerne $[\mathrm{L}]$ and pasture $[\mathrm{P}]$ ) combined with three levels of concentrate (air-dry basis), $0 \mathrm{~g}[\mathrm{CO}], 300 \mathrm{~g}[\mathrm{C} 3]$ or $600 \mathrm{~g} / \mathrm{d}$ [C6]. The pasture was composed mostly of Trifolium repens, Lolium perenne and Festuca pratensis. The six treatment combinations were LC0, LC3, LC6, PC0, PC3 and PC6. Concentrate composition ( $\%$ of DM) was: barley 50 , soyabean meal 45 , dicalcium phosphate 1.3 , calcium carbonate 1.2 , sodium chloride 2 and vitamin-mineral mixture 0.5 .

\section{Measurements and analysis}

Concentrate was offered at 09:00 h each day and forage was fed in two meals $(10: 00 \mathrm{~h}$ and 17:00 h). Hay residues were collected before feeding on the following day and weighed. The amount consumed was used to determine the amount of forage to be offered on the following day to maintain approximently $20 \%$ refusal of that offered (air-dry basis).

Representative samples of feeds were collected weekly for determination of dry matter (DM), nitrogen by the Kjeldahl method, ash (AOAC, 1980), neutral 
detergent fibre (NDF), acid detergent fibre (ADF) and cellulose (Goering and Van Soest, 1970). Cellulose was subtracted from ADF to yield lignin.

Apparent digestibilities of DM, organic matter, and cell wall constituents in the feedstuffs wcre determined in a previous sheep digestibility trial (Castro et al., 1991).

Ewes were weighed on days 105 of pregnancy. In addition, they were weighed twice week 14 before the morning feeding until lambing. Ewes and lambs were weighed $6 \mathrm{~h}$ after lambing.

\section{Statistical analysis}

Data were subjected to variance and covariance analysis using Statgraphics (Statistical Graphics Corporation, 1986) with forage, concentrate and the forage $\mathrm{x}$ concentrate interaction in the statistical model.

For each studied pregnancy week, the differences between substitution rate were analysed based on proccdure to comparing regression lines (Scber, 1977).

Multiple regression to predict voluntary hay intake was conducted using Stepwise Method with SPSS/PC +. Terms were added, in step-wise fashion, using forward selection and were only retained if they produced a significant reduction in the residual mean square.

\section{RESULTS}

\section{Feed composition}

Table 1 presents the nutrient composition of the feedstuffs.

TABLE 1

Chemical composition (DM basis), digestibility and metabolizable energy of forages and concentrate supplement fed to Churra ewes

\begin{tabular}{lccc}
\hline \multicolumn{1}{c}{ ltem } & Lucerne hay & Pasturc hay & Concentrate \\
\hline Chemical composition: & & & \\
Dry matter & 87.0 & 86.77 & 90.1 \\
Crude protein (Nx6.25) & 17.7 & 9.07 & 24.6 \\
Ash & 7.8 & 7.27 & 7.3 \\
NDF & 40.9 & 59.87 & 21.0 \\
ADF & 30.4 & 31.37 & 6.6 \\
Cellulose & 21.7 & 26.57 & 5.5 \\
Lignin & 8.6 & 4.97 & 1.1 \\
\hline Digestibility, \%: & & & \\
DMD & 66.6 & 70.07 & 84.1 \\
OMD & 69.5 & 71.97 & 87.3 \\
ME & 2.6 & 2.67 & 3.2 \\
\hline
\end{tabular}

${ }^{2} \mathrm{ME}=$ metabolizable cncrgy (Mcal $/ \mathrm{Kg} \mathrm{DM}$ ) cstimated from digestible organic matter content (Blaxter and Wainman, 1964) 


\section{Feed intake}

Voluntary DM intakes (VDMI) for the two hays are given in Table 2. When no concentrate was fed, VDMI of pasture hay was slightly, but non significantly $(P \geqslant 0.05)$, higher than that of lucerne hay, however, but when concentrate was fed, VDMI of lucerne hay tended to be higher. Hay intake decreased with increasing levels of concentrates.

Variations in VIDMI showed similar patterns for the two hays. The hay intake tended to increase from the 16 th to 18 th week of pregnancy and then decreased before lambing. Total dry matter intake (TDMI) was unaffected by the level of concentrate or by type of forage (Table 2).

TABI.F: 2

Efrect of type of forage, concentrate level and interaction on voluntary hay DM intake (VDMI) of hay, total DM intake (TDMI), and metabolizable cnergy intake (MEI)

\begin{tabular}{|c|c|c|c|c|c|c|c|c|c|}
\hline & \multicolumn{3}{|c|}{ l.ucerne hay } & \multicolumn{3}{|c|}{ Pasture hay } & \multirow[b]{2}{*}{$\mathrm{F}$} & \multirow[b]{2}{*}{$C$} & \multirow[b]{2}{*}{ SEM } \\
\hline & $\mathrm{CO}$ & $\mathrm{C} 3$ & $\mathrm{Cb}$ & $\mathrm{CO}$ & $C 3$ & $\mathrm{C} 6$ & & & \\
\hline \multicolumn{10}{|l|}{ VDMI, g /d } \\
\hline $16^{\mathrm{a}}$ & 1131 & 979 & 810 & 1125 & 823 & 694 & NS & $* * *$ & 51 \\
\hline 17 & 1273 & 1026 & 818 & 1309 & 882 & 711 & NS & $* * *$ & 75 \\
\hline 18 & 1248 & 1148 & 887 & 1379 & 999 & 726 & NS & $* * *$ & 89 \\
\hline 19 & 1245 & 1089 & 795 & 1347 & 927 & 719 & NS & $* * *$ & 73 \\
\hline 20 & 1049 & 988 & 705 & 1339 & 892 & 635 & NS & $* * *$ & 83 \\
\hline Average & 1182 & 1046 & 803 & 1300 & 903 & 697 & NS & $* * *$ & 64 \\
\hline $\operatorname{TDMI}(\mathrm{g} / \mathrm{d})$ & 1182 & 1316 & 1343 & 1300 & 1173 & 1237 & NS & NS & 45 \\
\hline $\operatorname{MEl}(\mathrm{Mcal} / \mathrm{d})$ & 3.00 & 3.42 & 3.84 & 3.40 & 3.10 & 3.52 & NS & $*$ & 0.15 \\
\hline
\end{tabular}

${ }^{a}$ Week of pregnancy

SEM $=$ pooled standard error of the mean

***, $P \leqslant 0.001, *, P \leqslant 0.05$

There was no significant interaction between forages and concentrate levels. Covariate was significant $(P \leqslant 0.001)$

By Churra ewes introducing weekly mean ewe body weight as a covariate

TABLE 3

Substitution rate between forage and concentrate intake (DMl)

\begin{tabular}{ccc}
\hline Week of pregnancy & Lucerne hay & Pasture hay \\
\hline 16 & $0.594 \pm 0.186$ & $0.798 \pm 0.137$ \\
17 & $0.777 \pm 0.190$ & $1.108 \pm 0.232$ \\
18 & $0.671 \pm 0.227$ & $1.209 \pm 0.263$ \\
19 & $0.833 \pm 0.231$ & $1.163 \pm 0.244$ \\
20 & $0.636 \pm 0.248$ & $1.303 \pm 0.228$ \\
\hline
\end{tabular}


Intake of digestible organic matter (DOM) by each ewe was calculated from data obtained in a digestibility trial (Castro et al., 1991). Intakes of metabolizable energy (MEI) were calculated from the intake of DOM using the equations of Blaxter and Wainman (1964).

The main effects of concentrates (Table 2) were significant $(P \leqslant 0.05)$ and MEI increasing with increasing concentrate level. Highest intake of ME was 3.84 and $3.52 \mathrm{Mcal} / \mathrm{d}$ by ewes on LC6 and PC6 treatments, respectively. There were no significant forage $x$ concentrate interactions $(P \geqslant 0.05)$ on VDMI, TDMI and MEI.

Substitution rates (SR) were calculated from regression analysis relating VDMI of hay and concentrate intake (DM basis) and tested differences in slopes. The SR were similar for both hays in different wecks of pregnancy (Table 3).

Ewe live weight and litter weight

Ewes gained an average of $5.18 \mathrm{~kg}$ from d 110 until lambing. Between day 110 and lambing, ewes offered higher levels of concentrate gained more $(P \leqslant 0.05)$. Also there was a slight increase in litter weight $(6 \mathrm{~h}$ postpartum) as concentrate levels increased (Table 4).

\section{DISCUSSION}

Effect of concentrate level on voluntary hay intake

Offering more concentrate in late pregnancy to Churra ewes reduced intake of the two hays, with a greater decrease of the pasture hay. Ewes receiving forage only had higher intakes of pasture hay (70\% DMD) than of lucerne hay $(66.6 \%$ DMD). When concentrate was fed, the VDMI of hay was greater for lucerne hay. These results with those of Orr and Treacher (1984) and Orr et al. (1985) who observed that when ewes in late pregnancy were given diets with varying

TABLE 4

Ewe live weight change and litter weight ( $\mathrm{kg}$ ) of Churra ewes fed different levels of concentrate with different forages in late pregnancy

\begin{tabular}{|c|c|c|c|c|c|c|c|c|c|}
\hline & \multicolumn{3}{|c|}{ Lucerne hay } & \multicolumn{3}{|c|}{ Pasture hay } & \multirow[b]{2}{*}{$\mathrm{F}$} & \multirow[b]{2}{*}{ C } & \multirow[b]{2}{*}{ SEM } \\
\hline & $\mathrm{CO}$ & $\mathrm{C} 3$ & $\overline{C 6}$ & $\mathrm{CO}$ & $\mathrm{C3}$ & $\mathrm{C6}^{-}$ & & & \\
\hline Live & 4.20 & 6.39 & 6.53 & 4.12 & 4.57 & 5.45 & NS & * & 0.67 \\
\hline Wci & 11.4 & 9.03 & 10.4 & 9.76 & 8.96 & 9.15 & NS & NS & 0.77 \\
\hline Litter weight & 5.79 & 6.02 & 6.04 & 4.59 & 5.08 & 6.41 & NS & NS & 0.69 \\
\hline
\end{tabular}

$\mathrm{a}, \mathrm{b}$ - ewe live weight change from day 110 to lambing 
proportions of concentrates and two hays available on mais ad libitum basis, VDMI of hays declined as the amount of concentrate increased, with greater declines in VDMI of the more digestible hay.

When forage and concentrate with a high protein content are offered, the voluntary forage intake increases, only when the amount of protein in the forage is less than $8 \%$ of DM (Osbourn, 1967). The pasture hay in this experiment contained $9 \% \mathrm{CP}$ which is more than the level at which Osbourn (1967) suggested that protein intake may be limiting.

Regression analysis of data for intake in this experiment gave the following equation to predict VDMI between weck 16 and lambing:

$$
\begin{array}{r}
\mathrm{VDMI}=24.162 \times \mathrm{BW}-0.019 \mathrm{C} \times \mathrm{DMD}-65.316 \times \mathrm{LW}-23.470 \times \\
\mathrm{x} \text { DMD }+0.085 \times \mathrm{C} \times \mathrm{LW}+1582.874
\end{array}
$$

where

Residual se $=176 ; r=0.80 ; r^{2}=0.65 ; P \leqslant 0.001 ; n=180$
VDMI = voluntary intake of hay $(\mathrm{g}$ of DM/day)
$\mathrm{BW}=$ body weight of ewes at the beginning of this experiment $(\mathrm{kg})$
$\mathrm{C}=$ intake of concentrate ( $\mathrm{g}$ of DM/day)
DMD $=$ dry matter digestibility of hay $(\%)$ and
LW $=$ litter weight $(\mathrm{kg})$.

This equation explained $65 \%$ of the observed variance with a standard error of $176 \mathrm{~g}$ and is slightly less precise than results obtained from day 105 of pregnancy until lambing with four hays (Orr and Treacher, 1984; $\mathrm{r}^{2}=0.72$; residual S.D. $=273$ ). Predictability of this equation is similar to the results of Trabalza-Marinucci et al. $(1992)\left(\mathrm{r}^{2}=0.67\right.$; residual S.D. $\left.=127\right)$ based on data from Sardinian ewes in the 5th month of pregnancy.

During the last week of pregnancy, there was no effect $(P \geqslant 0.05)$ of type of forage and level of concentrate on total DMI. It has been suggested that pregnant ewes try to meet its nutrient requirements by regulation of total DMI in the last days of pregnancy (Bines, 1976; Jarrige, 1981). Forbes (1977) observed that from the 10th week of pregnancy, intake of poor quality feed (55\% DMD) was depressed, presumably due to growth of the uterus and decreasing rumen volume, while medium-quality and high-quality diets (65 and 75\% DMD) were eaten in increasing quantities. However, in the 12th week of pregnancy, competition for space in the abdomen was such that physically control of intake superseded metabolic control for the medium diet, and the upward trend of feed intake was reversed. The $75 \%$ digestible diet allowed feed intake to increase parallel with nutrient requirements until the 18 th week of pregnancy, at which time the increasing rate of oestrogen secretion intervened and intake declined to parturition. In our experiment, VDMI increased from the 16 to 18 th week of 
pregnancy (DMD of different diets ranged from 66.6 to $78.1 \%$ ) and then decreased until lambing in a manner similar to that observed by Tissier et al. (1977).

Ewe live weight and litter weight

Higher live-weight gains in this study are comparable to those of Ledin (1986), Orr and Treacher (1984), Orr et al. (1985). Weight lost at lambing increased, as might be expected, with litter weight $(P \leqslant 0.001)$. The regression equation was as follows:

where

$$
\begin{aligned}
& \mathrm{Y}=2.64+1.23 \mathrm{LW} \\
& \mathrm{SE}=1.99 ; \quad \mathrm{r}=0.75 ; \quad \mathrm{P} \leqslant 0.001
\end{aligned}
$$

$\mathrm{Y}=$ weight lost at lambing $(\mathrm{kg})$

$\mathrm{LW}=$ litter weight $(\mathrm{kg})$.

In order to describe energy requirements for $\mathrm{BW}$ gains and facilitate comparison with other studies, BW change, ME intake, and LW were related by regression analysis:

where

$$
\begin{aligned}
& \mathrm{Y}=64.639 \mathrm{ME}+10.879 \mathrm{LW}-47.302 \\
& \mathrm{SE}=11.32 ; \quad \mathrm{r}=0.53 ; \quad \mathrm{P} \leqslant 0.01
\end{aligned}
$$

$\mathrm{Y}=$ body weight change (g/day)

$\mathrm{ME}=$ metabolizable energy intake $(\mathrm{kcal} / \mathrm{day})$

$\mathbf{L W}=$ litter weight $(\mathrm{kg})$.

The gain required to compensate weight lost at lambing by ewes carrying a $4 \mathrm{~kg}$ litter may be calculated from equation [2] as $7.5 \mathrm{~kg} \mathrm{(216} \mathrm{g/d} \mathrm{during} \mathrm{the} \mathrm{last}$ 35 th day of gestation). Thus, for a gain of $216 \mathrm{~g} / \mathrm{d}$, the requirement is $3.4 \mathrm{Mcal}$ of $\mathrm{ME} / \mathrm{d}$ (equation [3]). This energy intake was similar to that observed by Lauzurica (1989) with Manchega ewes.

\section{CONCLUSIONS}

In practice, prediction of performance and formulation of diets are based on predicted DMI. There are still some difficulties in accurately for the voluntary intake of forage by ruminants. This reflects incomplete knowledgement of the relationship between several factors affecting the voluntary intake. Therefore, further research is required to achieve better prediction accuracy for DMI.

Major improvements in the ability to predict DMI will require better description of the characteristics of the basal roughage and the ability to relate 
these characteristics to its potential intake. Completed with this will be the need to predict the effect of supplementary concentrates on the intake of roughages of different intake characteristics.

\section{REFERENCES}

ARC, 1980. The Nutrient Requirements of Ruminant Livestock. Commonwealth Agric. Burcaux, London

$\Lambda O \Lambda C, 1980$. Official Mcthods of Analysis. 13th ed. Association of Official Analytical Chemists. Washington, DC

Bines J.A., 1976. Factors influencing voluntary food intake in cattle. In: H. Swan and W.J. Broster (Editors). Principles of Cattle Production. Butterworths, London, pp. 287-305

Blaxter K.L., Wainman F.W., 1964. The utilization of the energy of different rations by sheep and cattlc for maintenance and for fattening. J. Agric. Sci., Camb. 63, 113-128

Bocquier F., Thériez. M., Brelurut A., 1987. The voluntary hay intake by cwes during the first weeks of lactation. Anim. Prod. 44, 387-394

Castrillo O., Guada J.A., 1979. Influencia de la ingestion y contenido energético de la dieta sobre las variaciones ponderales de ovejas gestantes y de los cordcros al nacimicnto. IV Jornadas Cientificas de la S.E.O. Laragoza, Espana, pp. 253-262

Castro T., Bermudez F.F., Sanz Arias R., 1991. Efecto de la relacion forraje: concentrado de la ración sobre la digestibilidad de la materia seca y los componentes de la pared celular. Arch. Zootec. $40,85-90$

Forbes J.M., 1970. Voluntary food intake of pregnant cwc. J. Anim. Sci. 31, 1222-1227

Forbes J.M., 1977. Interrclationships between physical and metabolic control of voluntary food intake in fattening, pregnant and lactating mature sheep: $\Lambda$ model. $\Lambda$ nim. Prod. $24,90-101$

Goering H.K., Van Soest P.J., 1970. Forage Fiber Analysis (apparatus, reagents, procedures and some applications). Agric. Handbook 379. ARS, USDA, Washington, DC

Guada J.A., Ovejero F.J., 1977. Efecto del plano de ingestion durante el ultimo tercio de la gestación sobre algunas caracteristicas productivas de la oveja Churra. Rev.Nutr. Anim. 15, 23-36

INRA, 1988. Alimentations des Bovins et Caprins, INRA Publ., Paris, France

Jarrige R.. 1981 . Consumo de alimentos y de agua. In: Alimentación de los Rumiantes. Mundiprensa, Madrid, España, pp. 192-222

Lauzurica S., 1989. Efecto del aporte de distintas cantidades de concentrado en ovejas al final de la gestación, sobre la capacidad de consumo de materia seca y sus producciones. Tesis Doctoral. Facultad de Veterinaria. Univerisdad Complutense, Madrid, España

Ledin I., 1986. Fffect of three different levels of concentrate in late pregnancy on ewe and lamb performance. Swedish J. Agric. Res. 16, 129-135

NRC, 1985. Nutrient Requirements of Domestic Animals. Nutrient Requirements of Sheep. (Sixth Revised Edition). National Academy Press. Washington, DC

Orr R.J., Treacher T.T., 1984. The effect of concentrate level on the intake of hays by ewes in late pregnancy. Anim. Prod. 39, 89-98

Orr R.J., Treacher T.T., Manson V.C.. 1985. The effect of ammonia treatment on the intake of straw and hay when offered with rations of concentrate to ewes in late pregnancy. Anim. Prod. 40. 101-109

Osbourn D.F., 1967. The intake of conserved forages. In: R.J. Wilkins (Editor). Fodder Conservation. Occasional Symposium British Grassland Sociely No 3, pp. 20-28 
Seber, G.A.F., 1977. Linear Regression Analysis. John Wiley \& Sons. New York

Statical Graphics Corporation. 1986. Staticalgraphics User`s Guide. Rockville. Maryland. U.S.A. Tissier M., Theriez M., Molenat G., 1977. Evolution des quantities d’aliment ingérées par la brebis à la fin de la gestation et au début de la lactation. Incidences sur les performances. II Ration à base d' ensilage de mais et foin. Ann. Zootech. 24. 149-166

Træabalza-Marinucci M., Verini-Supplizi A., Valfré F., Olivieri O., 1992. Voluntary hay intake by Sardinian ewes during last weeks of pregnancy and lactation. Small Ruminant Res. 7, 203-213

\section{STRESZCZENIE}

Pobranie i wykorzystanie dawek o różnym stosunku pasz objętościowych do treściwych przez maciorki w późnym okresie ciąży przy żywieniu do woli

Trzydziestu szésciu maciorkom rasy Churra, od 110 dnia ciąży do wykocenia, podawano dawki o 3 poziomach paszy treściwej $(0,300$ lub $600 \mathrm{~g} /$ dzień) przy skarmianiu do woli 2 rodzajów siana ( lucerny, o strawności SM $66.6 \%$ lub łąkowego, o strawności SM 70.0\%). Owce z.jadały nieco więcej siana łạkowego niż z lucerny. gdy stanowiło ono jedyną paszę. Dodatek paszy treściwej zmniejszal pobicranic siana, przy czym w większym stopniu łąkowego niż z lucerny. W miarę postępująccj ciąży zwiękşało się pobieranie siana, osiągając maksimum w 18 lygodniu cią̧y. Całkowita ilość zjedronej suchej masy byla podobna we wszystkich grupach żywieniowych.

Na podstawic uzyskanych wyników wyprowadzono równanic pozwalające na oszacowanic ilości pobieranego siana jako funkcji strawności jego suchej masy, pobrania paszy treściwcj. ciężaru maciorki i ciężaru miotu. 